\title{
Influence of Non-Economic
}

\section{Factors in the Use of Personal}

Care Products: The Case of Male

\section{Peruvian Consumer}

Influencia de factores no económicos en el uso de productos de cuidado personal: el caso del consumidor masculino peruano

Influência de fatores não econômicos no uso de produtos de cuidado pessoal: o caso do consumidor masculino peruano

\author{
Otto Regalado Pezúa \\ Carlos Alberto Guerrero Medina ${ }^{\star *}$ \\ Jessica Noelia Alzamora Ruiz \\ Jaime Briceño Morales
}

* PhD in Management Sciences at Université de Nice Sophia Antipolis (Niza, France). Master in Quantitative Marketing at Université Pierre Mendes (Grenoble, France). MBA at ESAN Graduate School of Business (Lima, Peru). Head of Academic Marketing Area and professor of ESAN Graduate School of Business. Correo electrónico: oregalado@esan.edu.pe. Postal address: Universidad ESAN, Alonso de Molina 1652, Monterrico, Surco, Lima, Perú.

** MBA at ESAN Graduate School of Business (Lima, Peru). Master in Marketing Intelligence at ESIC (Madrid, Spain). Bachelor of Sociology at Pontificia Universidad Católica del Perú (Lima, Perú). Researcher at ESAN Graduate School of Business. Correo electrónico: cguerrero@esan.edu.pe

*** MBA at ESAN Graduate School of Business (Lima, Peru). Bachelor of Economics at Universidad Federico Villarreal (Lima, Perú). Researcher at ESAN Graduate School of Business. Correo electrónico: jalzamora@esan.edu.pe

${ }^{* * * *}$ Master in Marketing at ESAN Graduate School of Business (Lima, Peru). Master in Marketing Intelligence at ESIC (Madrid, Spain). Bachelor of Marketing at Universidad San Ignacio de Loyola (Lima, Perú). Academic Coordinator and professor at Universidad San Ignacio de Loyola. Correo electrónico: jbriceno@usil.edu.pe 
Fecha de recibido: 12 de diciembre de 2015

Fecha de aprobado: 8 de febrero de 2016

Doi: http://dx.doi.org/10.12804/rev.univ.empresa.31.2016.06

Para citar: Regalado Pezúa, O., Guerrero Medina, C.A., Alzamora Ruiz, J.N., \& Briceño Morales, J. (2016). Influence of Non-Economic Factors in the Use of Personal Care Products: The Case of Male Peruvian Consumer. Universidad \& Empresa 18/31), 121-138. Doi: http://dx.doi.org/10.12804/rev.univ.empresa.31.2016.06

\section{ABSTRACT}

Over the past decade, the consumption of male personal care products and services has increased considerably on a global scale. In the case of the Peruvian market, this phenomenon is still incipient despite a favorable economic outlook that has boosted the consumption in different categories. This research identifies the impact of non-economic factors that influence on the consumption decision of personal care products and services for the male segment. To do this, the authors have used the Theory of Planned Behavior of Ajzen in a survey applied to 18 - 60 years old men. The results show that male consumers' perception of his environment (subjective norm) was limiting the intention of consumption of personal care products, even though the male consumer has a positive attitude toward using of these products. These factors would reflect the existence of deeply rooted taboos in Peruvian culture, based on a traditional view of man. Findings seek to contribute to developing of marketing strategies that reduce the impact of the subjective norm in the consumption decision of this kind of products and services.

Keywords: Consumer behavior, Non-economic factors, Theory of planned behavior, Male personal care products.

\section{RESUMEN}

Durante la última década el consumo de productos de cuidado personal masculinos y servicios ha incrementado considerablemente en una escala global. En el caso del mercado peruano, este fenómeno continúa incipiente a pesar de que el panorama económico favorable haya incrementado el consumo en diferentes categorías. Esta investigación identifica el imparto de factores no económicos en la decisión del consumo de productos de cuidado personal y servicios masculinos. Para esto, los autores han aplicado la teoría del comportamiento planeado de Ajzen en una encuesta aplicada a hombres de 18 a 60 años de edad. Los resultados muestran que los consumidores masculinos limitaban su intención de consumo de productos de cuidado personal dada la percepción de su entorno (norma subjetiva), a pesar de esto el consumidor masculino tiene una actitud positiva con respecto al uso de estos productos. Estos factores reflejan la existencia de tabús profundamente marcados en la cultura peruana, basados en la visión tradicional del hombre. Los resultados buscan contribuir al desarrollo de estrategias de marketing que reduzcan el imparto de normas subjetivas en la decisión de consumo de este tipo de productos y servicios.

Palabras clave: comportamiento del consumidor, factores no económicos, teoría del comportamiento planeado, productos de cuidado personal masculinos. 


\section{RESUMO}

Durante a última década o consumo de produtos de cuidado pessoal masculino e serviços tem incrementado consideravelmente em uma escala global. No caso do mercado peruano, este fenômeno continua incipiente apesar de que o panorama econômico favorável tenha incrementado o consumo em diferentes categorias. Esta pesquisa identifica o impacto de fatores econômicos na decisão do consumo de produtos de cuidado pessoal e serviços masculinos. Para isto, os autores têm aplicado a teoria do comportamento planejado de Ajzen em um inquérito aplicado a homens de 18 a 60 anos de idade. Os resultados mostram que os consumidores masculinos limitavam a sua intenção de consumo de produtos de cuidado pessoal dada a percepção de seu entorno (norma subjetiva); apesar disto o consumidor masculino tem uma atitude positiva com respeito ao uso destes produtos. Estes fatores refletem a existência de tabus profundamente marcados na cultura peruana, baseado na visão tradicional do homem. Os resultados buscam contribuir ao desenvolvimento de estratégias de marketing que reduzam o impacto de normas subjetivas na decisão de consumo deste tipo de produtos e serviços.

Palavras-chave: Comportamento do consumidor, fatores não econômicos, teoria do comportamento planejado, produtos de cuidado pessoal masculinos.

\section{INTRODUCTION}

Concern about beauty and personal care has become a major global trend. In that regard, a study by Nielsen in 55 countries reveals $90 \%$ of the people worldwide buy products in the health \& beauty category because they value looking good (Nielsen, 2010, p.1). In the last years, the male segment has added momentum to this category. Men have abandoned the traditional idea of just staying clean and have evolved towards looking healthy, being physically attractive, staying young and being self-conscious about their appearance (Nizar \& Mariam, 2009).

As male demand grew, supply responded immediately to cover the needs of these consumers. The industry's main players have started focusing on this segment by reorganizing their value proposition and developing new products. As proof of which, a study by Mintel reveals that new product launches in personal care \& beauty category targeting the male public grew $70 \%$ globally between 2007 and 2012. Additionally, to respond to this demand, markets have been increasingly segmented and expanded to include new products and needs (Mintel, 2013).

The situation has not been different in Latin America. According to Euromonitor, between 2004 and 2009 the male personal care market in this region grew at an annual $14.8 \%$ rate from US\$ 2.4 billion to 
US\$ 4.87 billion. This same source points to Brazil and Chile as the markets with the highest development potential region wide (as quoted in Tungate, 2011, p. 166).

In Peru, demand patterns in this segment have not evolved at the same pace as in other regional markets, despite the country having undergone similar economic consolidation processes. Between 2005 and 2014 Peru's economy has grown faster than $5 \%$ per year, making it one of the most prosperous country in the region (World Bank, 2015). A stronger economy has added momentum to domestic demand and expanded the middle class. New consumers with greater purchasing power are more interested in, and more demanding about, products with greater value added, leading to changing demand patterns (Ipsos Peru, 2013, p.15). Industries such as food and entertainment, among others, have benefited from these changes. However, the male personal care sector has remained conservative and shown incipient penetration, compared to other countries (Table 1 shows consumption per capita of this category in different countries of Latin America).

Table 1. Consumption per capita of male personal care products in Latin America Region

\begin{tabular}{|l|c|c|c|c|c|c|c|c|c|c|c|c|}
\hline & 2006 & 2007 & 2008 & 2009 & 2010 & 2011 & 2012 & 2013 & 2014 & $2015^{*}$ & $2016^{*}$ & Mean \\
\hline Latin America & 5,4 & 5,9 & 6,7 & 7,5 & 8,5 & 9,7 & 11,5 & 13 & 14,8 & 16,7 & 19 & 10,8 \\
\hline Brazil & 8,2 & 9 & 10,2 & 11,5 & 13,7 & 16,1 & 19,8 & 22,8 & 26,8 & 30,6 & 35,8 & 18,6 \\
\hline Chile & 11,6 & 12,2 & 13,3 & 13,9 & 14,4 & 15,4 & 17,1 & 18,4 & 19,8 & 21 & 22,2 & 16,3 \\
\hline Uruguay & 9,5 & 9,6 & 10,8 & 13,4 & 13,9 & 12,3 & 12,9 & 14,3 & 15,2 & 16,2 & 17,2 & 13,2 \\
\hline Costa Rica & 7,9 & 8,7 & 9,7 & 10,3 & 10,9 & 11,6 & 12,2 & 12,8 & 13,6 & 14,4 & 15,3 & 11,6 \\
\hline Venezuela & 3,4 & 3,6 & 4,4 & 6,9 & 8,9 & 11,1 & 11,9 & 13,2 & 16,7 & 21,1 & 25,9 & 11,6 \\
\hline Argentina & 3,9 & 4,6 & 5,8 & 6,7 & 8 & 9,7 & 12,2 & 15,9 & 17,8 & 20 & 22,3 & 11,5 \\
\hline Mexico & 4,7 & 5,1 & 5,6 & 5,8 & 6,3 & 6,8 & 7,7 & 8,2 & 8,8 & 9,4 & 10,1 & 7,1 \\
\hline Colombia & 5,1 & 5,3 & 5,9 & 6,2 & 6,5 & 6,7 & 7 & 7,1 & 7,5 & 8 & 8,4 & 6,7 \\
\hline Peru & 2,8 & 3,1 & 3,5 & 3,6 & 4,2 & 4,8 & 5,2 & 5,6 & 6 & 6,4 & 6,9 & 4,7 \\
\hline Ecuador & 3,4 & 3,6 & 3,9 & 4,1 & 4,3 & 4,6 & 4,9 & 5,2 & 5,4 & 5,6 & 5,9 & 4,6 \\
\hline $\begin{array}{l}\text { Dominican } \\
\text { Republic }\end{array}$ & 3,2 & 3,5 & 3,6 & 3,7 & 3,8 & 3,9 & 4,1 & 4,2 & 4,5 & 4,7 & 4,9 & 4 \\
\hline Guatemala & 2,2 & 2,3 & 2,5 & 2,6 & 2,7 & 2,8 & 3 & 3,1 & 3,3 & 3,5 & 3,7 & 2,9 \\
\hline Bolivia & 1,7 & 1,9 & 2 & 2,2 & 2,4 & 2,7 & 2,8 & 3,1 & 3,3 & 3,5 & 3,7 & 2,7 \\
\hline
\end{tabular}

* Forecast

Source: Passport Euromonitor, 2014 
This fact seemingly reflects the presence of certain non-economic factors that hamper growth of certain categories, such as the one under review. Against this backdrop, this study seeks to identify the influence of non-economic factors that trigger or inhibit the use of male personal care products in Metropolitan Lima (Peru's capital city), applying the Theory of Planned Behavior (TPB) as research framework and based on a survey among 300 men living in this city, in order to determine the influence of the "Attitude", "Subjective Norm" and "Control Perception" factors. Findings seek to contribute to developing of marketing strategies that reduce the impact of factors that inhibit the consumption decision of these products and services.

This paper is comprised of four sections. The first section presents the theoretical model that supports the research. The second section describes the methodology applied. The third section presents the findings obtained from the factorial and multiple linear regression analyses. Finally, the fourth section presents the discussion of results and conclusions.

\section{THEORETICAL FRAMEWORK}

Consumers' preferences and behavior toward specific products and services is a complex decision- making process that has been largely conceptualized through the Theory of Reasoned Action (Ajzen \& Fishbein, 1980). According to this model, the behavior of an individual depends on his or her intentions, conditioned by two elements: the individual's attitude when facing a given action (Attitude) and the perception of approval or disapproval of this action by the persons that make up the individual's social environment (Subjective Norm). This theory is based on the assumption that consumer are rational and consider all available information, both personal and social, before they act (Crawley \& Coe, 1990).

Despite the relevance of this theory, the TRA has been criticized for do not considerate the role of the context surrounding the behavior. The behavioral intention does not always lead to actual behavior because of circumstantial limitations. To surmount this limitation, Ajzen (1991) proposed an extension of his original model named Theory of Planned Behavior (TPB). This new model incorporates a third element as predictor of intention, the individual's own perception on his or her capacity to influence the final result (Control Perception).

The TPB has been applied to predict consumer behavior toward different 
products and markets, including personal care. This is the case of Hee, Yeon and Jae-Eun (2011) who examine the purchase intention of organic personal care products in USA; Hope, Dutra, Marques and De Matos (2012) who seek to explain patterns for organic goods consumption in Brazil; Hansen (2008) who analyzes the food purchase behaviors in Denmark; Truong (2009) when trying to predict the acceptance of online video services in France; Lee, Murphy and Swiller's (2009) who seek to explain the young people loyalty towards mobile phone; and Chang (2013) who analyze the recycling intentions. The use of this theory in this research confirms its relevance and robustness.

Both TRA and TPB are validated models that allow us to understand the consumption of male personal care products is not only determined by the purchasing power of customers. We choose the TPB over the TRA as the basis for this research because the consumption behavior of personal care products is subject to some uncertainty that not only depends on the attitude and Subjective Norm, but also on the facility or difficulty perceived that may interfere with behavior control (Netemeyer, Burton \& Johnston, 1991). The TRA, in contrast, applies to behavior with volitional control, to people who consider the impli- cations of their actions before they decide to engage in it (Leeman \& Ong, 2008).

Using concepts explored in previous research about consumer behavior, this research examines the relationshipbetweenintentiontousepersonal care products among male consumers and the following factors:

- Attitudes towards the use of personal care products. Under this factor, individuals make a positive or negative judgment about this specific behavior, influenced by their experience, previous knowledge and beliefs that the behavior leads to certain outcomes (Ajzen \& Fishbein, 1980). Many studies have shown the significant effect of Attitude toward intention to consume different mass consumer and specialized products (Buttle \& Bok, 1996; Beaudoin, Moore \& Goldsmith, 1998; Shih \& Fang, 2004). Thus, the hypothesis is proposed as: H1. There is a positive relation between Behavioral Attitude and the Intention to use personal care products among male consumers.

- Subjective Norm. This factor refers to the influence of the people belonging to the nearest environment (relatives, friends, related persons or role models) on the consumption behavior towards 
particular type of products (Chiou, 1998; Lee \& Green, 1991). In this case, the consumer takes into account the acceptance or rejection by a determined group to establish a behavior pattern that matches his or her expectations.

- Many studies have shown the significant effect of Subjective Norm toward intention to consume different mass consumer and specialized products (Johri \& Sahasakmontri, 1998; Wan, Chung-Leung \& Chow, 2005; Lee, Qu \& Kim, 2007). This research analyzes the impact of the rejection by the nearest environment toward the consumption of personal care products. Thus, the hypothesis is proposed as:

$\mathrm{H} 2$. There is a negative relation between Subjective Norm and the Intention to use personal care products among male consumers.
- Control Perception. This factor refers to the degree of control that a consumer perceives over performing a specific behavior (Chen, 2007). Many studies have shown the significant effect of Control Perception toward intention to consume different mass consumer and specialized products (Hansen, Jensen \& Solgaard, 2004; Chan \& Lau, 2001). In this specific case, the Control Perception is related to the limited presence of personal care products on the market and the consumer's ability to access them. Thus the hypothesis is proposed as:

H3. There is a negative relation between Control Perception and the Intention to use personal care products among male consumers.

Figure 1 shows the hypotheses considered.

Figure 1. Hypotheses

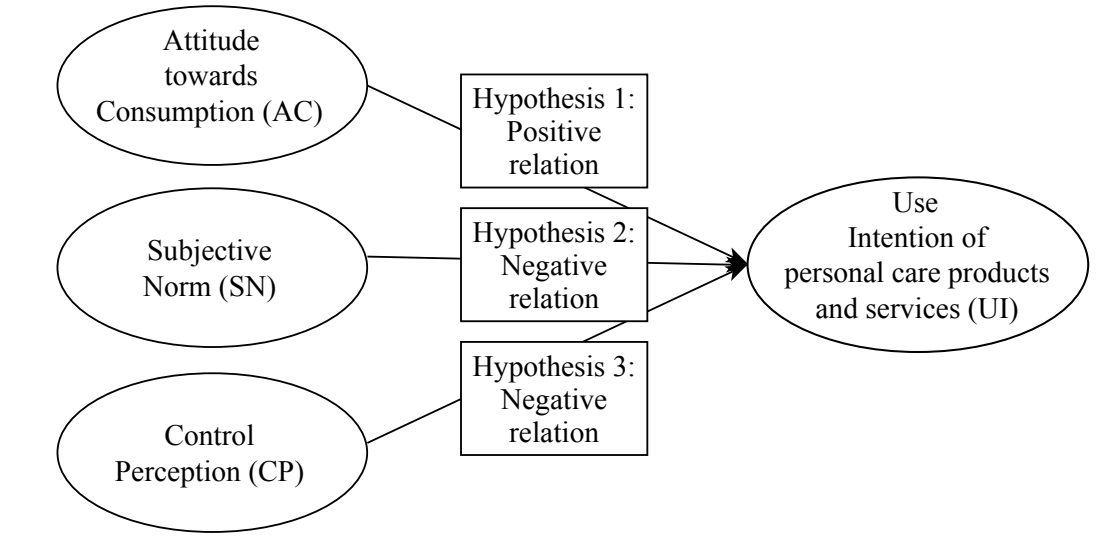

Source: own elaboration. 


\section{METHODOLOGY}

The measuring tool was a questionnaire designed taking into consideration three independent factors (Attitude - A, Subjective Norm SN, Control Perception - CP) and one dependent factor (Use Intention), based on the original Theory of Planned Behavior scale of Ajzen and on eight focus groups previously applied to Lima males of different ages. The scale and statements that were used in research performed elsewhere abroad were adapted to the local context. Industry participants and specialists in market research validated the final tool.

The tool's final version was comprised of eleven (11) statements that were individually evaluated using a seven level Likert scale to measure the respondents' level of agreement or disagreement. Additionally, five more descriptive questions on use habits and customs contributed to support the research hypotheses. Table 2 shows the dependent factors, the comprised statements and the dependent variable.

Table 2. Factors and statements

\begin{tabular}{|c|c|c|c|}
\hline Factor & $\begin{array}{l}\text { Type of factor } \\
\text { / variable }\end{array}$ & & Statements \\
\hline \multirow{5}{*}{ Attitude (A) } & \multirow{5}{*}{ Dependent } & P1_1 & Agreeable / Disagreeable to me \\
\hline & & P1_2 & Very manly / not manly at all \\
\hline & & P1_3 & Something a man should / should not do often \\
\hline & & P1_ 4 & Something a man should do as often as / less than a woman \\
\hline & & P1_5 & Unnecessary / necessary for a man \\
\hline \multirow{3}{*}{$\begin{array}{l}\text { Subjective } \\
\text { Norm (SN) }\end{array}$} & \multirow{3}{*}{ Dependent } & P2_1 & $\begin{array}{l}\text { Persons whose opinion I value think that a man should not } \\
\text { be too preoccupied about personal care products and services } \\
\text { they use }\end{array}$ \\
\hline & & P2_2 & $\begin{array}{l}\text { Persons whose opinion I value do not expect a man to use } \\
\text { many personal care products. }\end{array}$ \\
\hline & & $\mathrm{P} 2 \_3$ & $\begin{array}{l}\text { My male friends and close family members are not too } \\
\text { preoccupied by the personal care products they use. }\end{array}$ \\
\hline \multirow{2}{*}{$\begin{array}{l}\text { Control } \\
\text { Perception } \\
(\mathrm{CP})\end{array}$} & \multirow{2}{*}{ Dependent } & P3_2 & $\begin{array}{l}\text { In Peru there are not as many personal care products and } \\
\text { services for men as I would like }\end{array}$ \\
\hline & & P3_3 & $\begin{array}{l}\text { It is not very easy to find personal care products and services } \\
\text { for men like me. }\end{array}$ \\
\hline $\begin{array}{l}\text { Use } \\
\text { intention }\end{array}$ & Independent & P4_1 & $\begin{array}{l}\text { I'm interested in using more products and personal care } \\
\text { services }\end{array}$ \\
\hline
\end{tabular}

Source: own elaboration. 
To ensure survey respondents had a univocal understanding of the evaluated category (personal care products), they were presented with a standard definition that included pictures of the products and services included in this category. These products and services were compiled from different countries in the region with wider range of product offerings. Products that the Lima male consumer traditionally uses were included (shampoo for both men and women, gel, conditioner, perfume, shaving cream, talcum powder, male/ female cologne, unisex hair salon, and sauna), as well as more innovative products (hair-type targeted shampoo, skin cream, hair styling creams, specialized salons, facial treatments, spas, hair care products, waxing). After receiving confirmation from the survey respondents of their understanding of the category's scope and about their relation to the products and services from the perspective of their own consumption experience, the tool's application started.

The research sample population included men from 18 to 60 years old from the A, B and C socio-economic levels living in Metropolitan Lima. This city was selected because it concentrates $30 \%$ of Peruvian population and people residing in it coming from different parts of the country (Ipsos, 2013). Consumers belonging to highest socioeconomic levels were selected to ensure that the purchasing power does not influence in the intention to use personal care products. The sample was comprised of 300 cases, which allowed estimating results for the whole population with a confidence level of $95 \%$ and an error margin of $5.7 \%$, assuming maximum data dispersal $(\mathrm{p}=\mathrm{q}=50)$. The sample's descriptive statistics appear in Table 3.

Table 3. Surveyed persons' profile

\begin{tabular}{|l|c|c|}
\hline \multicolumn{1}{|c|}{ Demographics } & & Frequency $\%$ \\
\hline Sex & & \\
\hline Male & 300 & 100 \\
\hline Age (years) & & \\
\hline $18-24$ & 69 & 23 \\
\hline $25-34$ & 89 & 30 \\
\hline $35-46$ & 80 & 27 \\
\hline $47-60$ & 62 & 20 \\
\hline
\end{tabular}

Continúa 


\begin{tabular}{|c|c|c|}
\hline Demographics & & Frequency \% \\
\hline Socio-economic level (household monthly average income) & & \\
\hline A Socio economic level (above S/. 10726) & 27 & 9 \\
\hline B Socio economic level (S/. 10726 - 2996) & 87 & 29 \\
\hline C Socio economic level (S/. 2996- 1488) & 187 & 62 \\
\hline
\end{tabular}

Source: own elaboration.

Findings were analyzed in three steps. The first consisted of an exploratory factor analysis used to statistically validate the presence of the factors or constructs identified by the theory. The factors were analyzed by examining the correlation patterns between observed measurements. Statements with high correlation (positive or negative) were more likely to be influenced by the same factor, while less related statements were influenced by different factors (De Coster, 1998). In addition, Chronbach's Alfa was computed for each of the resulting factors to quantify their reliability or level of internal consistency.

The second stage of the analysis consisted in a multiple linear regression to validate the statistical existence of relations between the identified factors in the first stage and the dependent variable, and as well to determine the intensity of each of these relations. This method supported the study's hypotheses and established to what extent each factor explained the intention to use personal care products and services. The results from the regression analysis were verified by using a variance analysis (ANOVA) and evaluating their level of significance.

Finally, the results were discussed with a panel of industry participants to ensure the obtained information actually explained Lima consumers' behavior. To do this, we used the findings obtained through the descriptive questions in the questionnaire.

\section{RESULTS}

\subsection{Factorial analysis}

Our research support the existence of factors or constructs included in the study by our exploratory factor analysis using Principal Component Method and Varimax Rotation. Previously, KMO (Kaiser-MeyerOlkin) and Bartlett's sphericity tests were applied to evaluate the pertinence of performing a factor analysis on the results obtained through the study. The KMO tests yielded a 0.86 score (scores above 0.75 indicate 
the factor analysis is appropriate). Bartlett's sphericity resulted in a significance level below 5\%, invalidating the null hypothesis ( $\mathrm{H} 0$ : there is no significant correlation between the statements' measurements). Results obtained through factor analysis explain $65.7 \%$ of the total data.

Table 4 shows the loads for each of the ten (10) statements, the factors they belong to, and the results of the Cronbach Alpha Test that measure each factor's internal consistency. Findings from this test reveal each of the identified independent factors (Attitude towards consumption - A, Subjective Norm - SN, and Control Perception - CP) are internally valid. Consequently, the scores obtained through the Alpha Cronbach test (scores above 0.70 for each of the factors) and the revision performed by industry participants support the pertinence of the scales in the Peruvian context.

Table 4. Factor load and internal validity

\begin{tabular}{|c|c|c|c|}
\hline Factor & Statements & Item load & Cronbach Alpha \\
\hline \multirow{5}{*}{ Attitude (A) } & P1_1 &, 76 & \multirow{5}{*}{0,81} \\
\hline & P1_2 &, 08 & \\
\hline & $\mathrm{P} 1 \_3$ &, 61 & \\
\hline & P1_4 &, 59 & \\
\hline & P1_5 & ,79 & \\
\hline \multirow{3}{*}{ Subjective Norm (SN) } & $\mathrm{P} 2 \_1$ & ,88 & \multirow{3}{*}{0,85} \\
\hline & $\mathrm{P} 2 \_2$ &, 88 & \\
\hline & $\mathrm{P} 2 \_3$ &, 08 & \\
\hline \multirow{2}{*}{ Control Perception (CP) } & P3_2 &, 84 & \multirow{2}{*}{0,76} \\
\hline & P3_3 & 87 & \\
\hline
\end{tabular}

Source: own elaboration.

\subsection{Regression analysis}

The multiple linear regression analysis with the identified factors yielded an $\mathrm{R}^{2}$ of 0.665 . Consequently, the model explains $66.5 \%$ of the total data. Table 5 shows the level of influence (Beta - $\beta$ ) of each dependent factor towards UI (the higher the $\beta$ score in absolute terms, the higher the factor's influence on UI). The significance of the ANOVA test with a score below $5 \%$ permitted to reject the null hypothesis ( $\mathrm{H} 0: \beta \quad 1 \neq \beta 2 \neq \beta 3 \neq 0$ ). Additionally, the level of significance (Sig) obtained for each of the $\beta$ scores fell below $5 \%$, thus 
also rejecting the null hypothesis the independent factors and the (H0: there is no relation between dependent factor).

Table 5. Regression coefficients

\begin{tabular}{|l|c|c|c|c|c|}
\hline & standardized beta & Standard error & Beta- $\beta$ & $\mathrm{T}$ & Sig. \\
\hline Constant & 3,82 &, 03 & & 126,39 &, 00 \\
\hline Attitude (A) &, 419 &, 03 &, 59 & 13,83 &, 00 \\
\hline Subjective Norm (SN) &,- 23 &, 03 &,- 33 & $-7,73$ &, 00 \\
\hline Control Perception (CP) &,- 08 &, 03 &,- 11 & $-2,60$ &, 00 \\
\hline
\end{tabular}

Source: own elaboration.

Figure 2. Model findings

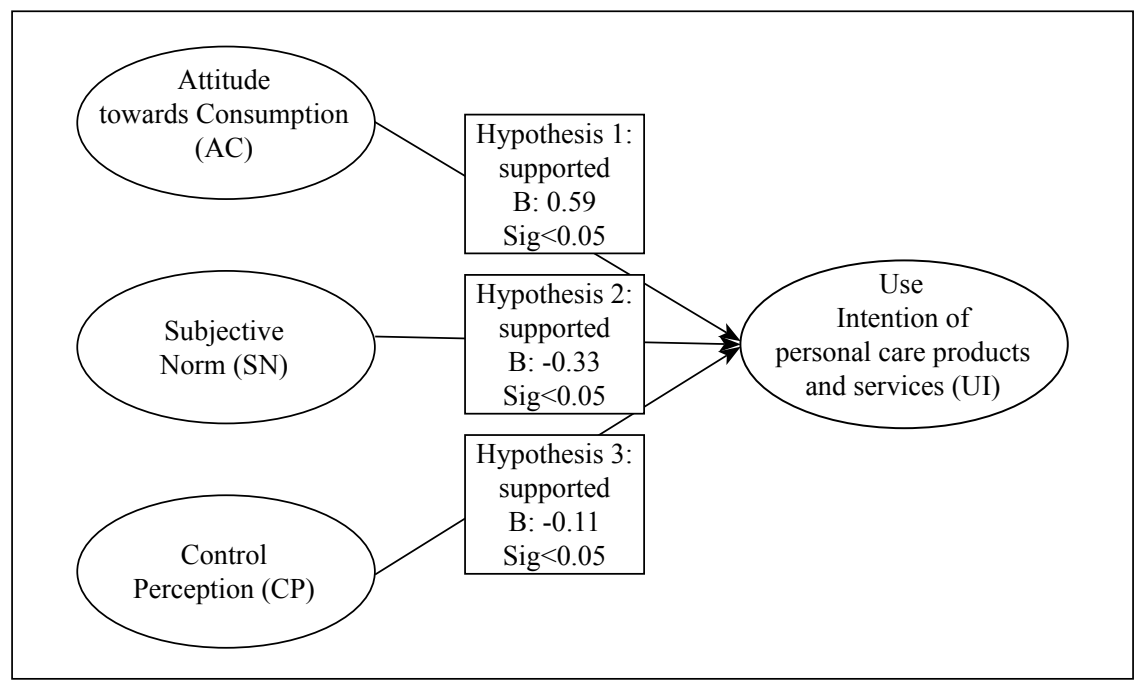

Source: own elaboration.

The main results are summarized in level, the Lima male subject perceiFigure 2. Results show that the At- ves the use of this category of protitude towards the consumption of ducts and services as a need for personal care products and services men (as much as women do), besiis the factor that has the most posi- des the fact that its use is a source tive influence towards the Use In- of satisfaction. These results suptention $(\beta=0.59)$. At an individual port the study's first hypothesis. 
The strong relation identified between Positive Attitude towards consumption and Use Intention is aligned with the interest of Lima male individuals to try new consumption experiences in the personal care category. At a descriptive level, the products and services generating the highest use interest among males within the analyzed category are the less traditional ones, as in Table 6 . Likewise, the consumer is prone to experience new brands in the category instead of adhering to existing ones (see Table 7).

Table 6. Comparison between use and use intention by product type

\begin{tabular}{|c|c|c|c|}
\hline $\begin{array}{l}\text { Product } \\
\text { type }\end{array}$ & Products & $\begin{array}{l}\text { Products used at least once } \\
\text { in the last } 12 \text { months }\end{array}$ & Interest in product use \\
\hline \multirow{11}{*}{$\begin{array}{l}\text { Traditional } \\
\text { products* }\end{array}$} & Perfume & $92 \%$ & $20 \%$ \\
\hline & Unisex salon & $82 \%$ & $10 \%$ \\
\hline & Shaving foam & $79 \%$ & $26 \%$ \\
\hline & Unisex shampoo & $69 \%$ & $15 \%$ \\
\hline & Talcum powder & $67 \%$ & $9 \%$ \\
\hline & After shave & $56 \%$ & $34 \%$ \\
\hline & Gel / hair fixing products & $38 \%$ & $12 \%$ \\
\hline & Bath cologne & $38 \%$ & $15 \%$ \\
\hline & Hair conditioner & $37 \%$ & $13 \%$ \\
\hline & Sauna & $37 \%$ & $43 \%$ \\
\hline & Massage & $35 \%$ & $55 \%$ \\
\hline \multirow{8}{*}{$\begin{array}{l}\text { Innovative } \\
\text { products** }\end{array}$} & Shampoo by hair type & $31 \%$ & $33 \%$ \\
\hline & Skin lotion & $31 \%$ & $30 \%$ \\
\hline & Styling cream & $24 \%$ & $19 \%$ \\
\hline & Specialized salon & $24 \%$ & $39 \%$ \\
\hline & Facial treatment & $12 \%$ & $32 \%$ \\
\hline & Spa & $11 \%$ & $45 \%$ \\
\hline & Hair care treatment & $8 \%$ & $27 \%$ \\
\hline & Waxing & $4 \%$ & $5 \%$ \\
\hline
\end{tabular}

* Products and services aimed at male segment with more than 5 years in the Peruvian market and used by $35 \%$ of the male segment or more.

** Products and services aimed at male segment with less than 5 years in the Peruvian market and used by less than $35 \%$ of male segment.

Source: own elaboration. 
Table 7. Openness to new brands

\begin{tabular}{|c|c|c|c|}
\hline $\begin{array}{l}\text { Product } \\
\text { type }\end{array}$ & Product & $\begin{array}{l}\text { I am not likely to change } \\
\text { the brand I use }\end{array}$ & $\begin{array}{c}\text { I am open to try new } \\
\text { brands }\end{array}$ \\
\hline \multirow{11}{*}{$\begin{array}{l}\text { Traditional } \\
\text { products* }\end{array}$} & Unisex salon & $43 \%$ & $57 \%$ \\
\hline & Massage & $40 \%$ & $60 \%$ \\
\hline & H\&S type shampoo & $27 \%$ & $73 \%$ \\
\hline & Aftershave & $37 \%$ & $63 \%$ \\
\hline & Shaving foam & $36 \%$ & $64 \%$ \\
\hline & Perfume & $35 \%$ & $65 \%$ \\
\hline & Bath cologne & $34 \%$ & $66 \%$ \\
\hline & Sauna & $34 \%$ & $66 \%$ \\
\hline & Gel / hair fixing products & $31 \%$ & $69 \%$ \\
\hline & Talcum powder & $27 \%$ & $73 \%$ \\
\hline & Hair conditioner & $26 \%$ & $74 \%$ \\
\hline \multirow{8}{*}{$\begin{array}{l}\text { Innovative } \\
\text { products** }\end{array}$} & Facial treatment & $43 \%$ & $57 \%$ \\
\hline & Waxing & $36 \%$ & $62 \%$ \\
\hline & Specialized salon & $35 \%$ & $65 \%$ \\
\hline & Skin lotion & $34 \%$ & $66 \%$ \\
\hline & Styling cream & $24 \%$ & $76 \%$ \\
\hline & Hair care treatment & $23 \%$ & $77 \%$ \\
\hline & Shampoo by hair type & $21 \%$ & $79 \%$ \\
\hline & Spa & $21 \%$ & $79 \%$ \\
\hline
\end{tabular}

* Products and services aimed at male segment with more than 5 years in the Peruvian market and used by $35 \%$ of the male segment or more.

** Products and services aimed at male segment with less than 5 years in the Peruvian market and used by less than $35 \%$ of male segment.

Source: own elaboration.

The Subjective Norm $(\beta=-0.33)$ has an important negative influence on the intention to use a product or service. This demonstrates how role models and the immediate environment considerably restrict the use of products and services in this category. These results allow supporting the second hypothesis presented in the research paper.

The Control Perception $(\beta=-0.11)$ has a negative, though weak, influence on the intention to use the 
product or service, i.e. Use Intention, demonstrating male consumers feel the Lima market does not yet provide the personal care products that they would like to have, although this does not considerably hamper their Use Intention. These results allow supporting our third hypothesis.

\section{DISCUSSION AND CONCLUSIONS}

Our findings show that the personal care category can grow in the Lima market thanks to the consumers' positive Attitude and their interest in trying new products, services and brands. The scores from the Control Perception factor may reveal a certain demand that is not met by the existing supply. Potential consumers expect to find a larger range of specialized products and services exclusively targeting the male public.

Despite these circumstances, the results under the Subjective Norm factor reflect the principal obstacle to expanding this category in the Peruvian market. Consumers seem to feel that persons from their social environment would reject the use of these products: This expected behavior would reflect the taboos deeply embedded in Peruvian culture, based on a traditional understanding of manhood that should not be related to attributes such as beauty, sensitivity and aesthetic self-awareness (Gutmann, 2003; Diekman, Eagly, Mladiñnic \& Ferreira, 2005). Cultural factors would influence substantially the development of this category.

Developing a brand strategy and a communications plan that are based on attributes that are not in conflict with the traditional vision of manliness would contribute to the short term increase of the potential of any initiative linked to the Lima market personal care category. In this respect, professional success and compensation for a hard day's work were identified in focus groups as potential attributes that could support a brand strategy for this category. The field of future studies will analyze the efficiency of these attributes in avoiding the negative effect that the social environment has on the Lima consumer's intention to purchase. Likewise, our findings will allow us to investigate in future the social environment's impact on the development of the male personal care category, in countries of the region with a different socio-cultural context, like Chile or Argentina.

As for other research studies that measure the factors affecting consumption of a given product or service, this study takes as starting point the behavioral intention before actual consumption. Even then, 
these findings seem acceptable since there is evidence of causal links between intention and consumption in the growing personal care rising market.

\section{REFERENCES}

Ajzen, I. (1991). The theory of planned behavior. Organizational Behavior and Human Decision Processes 50, 179-211.

Ajzen, I., \& Fishbein, M. (1980). Understanding attitudes and predicting social behavior. New Jersey: Prentice-Hall.

Beaudoin, P., Moore, M., \& Goldsmith, R. (1998). Yong fashion leaders and followers attitudes toward American and imported apparel. Journal of Product \& Brand Management, 7(3), 193207.

Buttle, F., \& Bok, B. (1996). Hotel marketing strategy and the theory of reasoned Action. International Journal of Contemporary Hospitality Management, 8(3), 5-10.

Chan, R., \& Lau, L. (2001). Explaining green purchasing behavior: A cross-cultural study on American and Chinese consumers Journal of International Consumer Marketing. 14(2,3), 9-40.

Chang, L. (2013). A moral basis for recycling: Extending the theory of planned behavior. Journal of
Environmental Psychology, 36, 96-102.

Chen, M. (2007). Consumers attitudes and purchase intentions in relation to organic foods in Taiwan: Moderating efects of food-related personality traits. Food Quality and Preferences 18(7), 1008-1021.

Chiou, J. (1998). The effects of attitude, subjective norm, and perceived behavioral control on consumers' purchase intentions: the moderating effects of product knowledge and attention to social comparison information. Proceedings of the National Science Council, Republic of China, 9(2), 298-308.

Crawley III, F., \& Coe, A. (1990), Determinants of middle school students' intention to enroll in a high school science course: An application of the theory of reasoned action. Journal of Research in Science Teaching, 27(5), 461-476.

DeCoster, J. (1998), Overview of Factor Analysis. Retrieved on June 15, 2015, from http://www. stat-help. com/notes.html

Diekman, A., Eagly, A., Mladiñnic, A., \& Ferreira, M. (2005). Dynamic Stereotypes about Women and Men in Latin America and the United States. Journal of Cross-Cultural Psychology 36, 209-226. 
Euromonitor (2014). Consumption in personal care products. Passport [Data base]. Retrieved on March 10, 2015, from http:// 200.38.75.93:2113/portal/statistics/rankcountries

Gutmann, M. (2003). Changing men and masculinities in Latin America (2a ed.). London: Duke University Press.

Hansen, T. (2008). Consumervalues, the theory of planned behavior and online grocery shopping. International Journal of Consumer Studies, 32(2), 128-137.

Hansen, T., Jensen, J. M., \& Solgaard, H. (2004). Predicting online grocery buying intention: a comparison of the theory of reasoned action and the theory of planned behavior. International Journal of Information Management, 24(6), 539-550.

Hee Yeon, K., \& Jae-Eun, C. (2011). Consumer purchase intention for organic personal care products. Journal Of Consumer Marketing, 28(1), 40-47.

Hope, A., Dutra, M., Marques, L., \& De Matos, C. (2012). Comportamento do consumidor de produtos orgânicos: umaaplicação da teoria do comportamento planejado. Revista de Administração e Contabilidade da Unisinos, 9(2), 174-188.

Ipsos Perú (2013). Informe Gerencial de Marketing - Liderazgo en productos de cuidado personal. (s. 1.): Ipsos Apoyo.

Johri, L., \& Sahasakmontri, K. (1998). Green marketing of cosmetics and toiletries in Thailand. The Journal of Consumer Marketing, 15(3), 265-281.

Lee, C., \& Green, R. T.(1991). Crosscultural examination of the Fishbein behavioral intentions model. Journal of International Business Studies, 22, 289-305.

Lee, H., Qu, H., \& Kim, Y. (2007). A study of the impact of personal innovativeness on online travel shopping behavior: a case study of Korean travelers. Tourism Management, 28, 886-897. Lee, R. Murphy, J., \& Swiller, E. (2009). The moderating influence of hedonic consumption in an extended theory of planned behavior. Service Industries Journal, 29(4), 539-555.

Leeman, O., \& Ong, J. (2008). Lost and Found Again: Subjective Norm in Gym Membership. DLSU Business \& Economics Review, 18(1), 13-27.

Mintel (2013), Beauty and personal care product launches targeted to men increase by $70 \%$ over the past six years. Retrieved on July 25, 2015, from http://www. mintel.com/press-centre/beautyand-personal-care/beauty-personal-care-product-launchesincrease-substantially. 
Netemeyer, R., Burton, S., \& Johnston, M. (1991). A comparison of two models for the prediction of volitional and goal-directed behaviors: A confirmatory analysis approach. Social Psychology Quarterly, 54(2), 87-100.

Nielsen (2010), Global Online Survey (Informe Num. Q1 2010). (s. 1.): The Nielsen Company.

Nizar, S., \& Mariam, D. (2009). Canadian and French men's consumption of cosmetics: a comparison of their attitudes and motivations. Journal of Consumer Marketing, 26(2), 97-109.

Shih, Y., \& Fang, K. (2004). The use of a decomposed theory of planned behavior to study Internet banking in Taiwan. Internet Research, 14(3), 13-223.
Tungate, M. (2011). Branded Beauty: How Marketing Changed the Way We Look. (s. 1.): Mark Tungate.

Truong, Y. (2009). An Evaluation of the Theory of Planned Behavior in Consumer Acceptance of Online Video and Television Services. Electronic Journal of Information Systems Evaluation, 12(2), 197-206.

Wan, W., Chung-Leung, C., \& Chow, C. (2005). Customers adoption of banking channels in Hong Kong. International Journal of Bank Marketing, 23, 255-272.

World Bank (2015). Perú Panorama general. Retrieved on October 25, 2015, from http://www.bancomundial.org/es/country/peru/ overview 